\title{
Hermit Crab (Decapoda, Anomura) Attraction to Dead Gastropod Baits in an Infralittoral Algae Bank
}

\author{
Juarez C. B. Pezzuti; Alexander Turra; and Fosca P. P. Leite* \\ Departamento de Zoologia; Instituto de Biologia; Unicamp; CEP 13083-970; Campinas - SP - Brazil
}

\begin{abstract}
Hermit crabs use gastropod shells as shelter and are adapted to follow chemical cues released from tissues of dead or injured gastropods as a way to find new and more adequate shells. The species composition, crab size, shell types adequacy and physical condition were compared between attracted individuals and crabs collected in previous samples. The previous sampling was carried out in five areas before each experiment. Then, five baits of crushed gastropods in nylon net bags were installed in these areas. Three samples were taken at 30min intervals, capturing all crabs within a circle of $60 \mathrm{~cm}$ diameter. Attraction of hermit crabs was tested for four different gastropod baits to verify specificity of the chemical cues. Clibanarius antillensis, Pagurus brevidactylus and Paguristes tortugae were collected in the study area. Pagurus brevidactylus, the smallest species, turned out to be more attracted than the 2 other species. The results showed that attracted crabs utilized more gastropod shell types than that collected in previous samples, however shell utilization pattern did not differ between them. Attracted animals were slightly smaller (shield length) than those collected in the previous samples but did not present significant differences in shell adequacy and condition. The four experimental baits attracted the crabs in similar ways not indicating a specific response from the crabs. The fact that attracted animals were smaller suggested that the attraction to dead gastropods might enable the acquisition of a new and larger shell and, consequently, chains of shell exchange between the attracted crabs.
\end{abstract}

Key words: Hermit crab, chemical attraction, gastropod predation sites, shell use, shell condition

\section{INTRODUCTION}

Intertidal hermit crabs need to carry and live in gastropod shells to protect themselves against predation and desiccation. Shells are also a limiting resource for these crabs and may regulate their fecundity (Childress, 1972; Bertness, 1981a), growth (Markham, 1968; Fotheringham, 1976; Bertness, 1981b), survival (Vance, 1972; Bertness, 1981c), copulatory success (Hazlett \& Baron,
1989), and intra- and interspecific interactions among them (Bach et al., 1976, Bertness, 1981a). Empty shells are generally scarce in the field. Thus new shells must be obtained through exchanges among the crabs or by encountering gastropods that are dead or injured. McLean (1974) made the first observation of chemical signals associated with a hermit crab attendance to predation sites (gastropods being eaten by a predator gastropod species). He described the behaviour of the

\footnotetext{
${ }^{*}$ Author for correspondence
} 
attracted crabs and the consequent establishment of a dominance hierarchy for the new available shell.

Therefore, hermit crabs can be attracted to predation sites or simulated gastropod predation events (McLean, 1974; Rittschof, 1980; Hazlett \& Herrnkind, 1980; Gilchrist \& Abele, 1984; Wilber \& Herrnkind, 1984; Lepore \& Gilchrist, 1988) by chemical cues from gastropod flesh (Rittschof, 1980). Attraction of hermit crabs is associated with behavioural plasticity that is modulated by intrinsic characteristics of the crab as its size or of the used shell (adequacy, physical condition, and diversity) (Gilchrist \& Abele, 1984).

The aim of this work was to investigate the species and sizes of hermit crabs attracted to dead gastropod baits in a Sargassum bed. In addition, shell utilization (type, size, adequacy, and physical condition) was compared between attracted and previously collected individuals to discuss the causes and consequences of this particular behaviour.

\section{MATERIAL AND METHODS}

The study was carried out in the rocky shore of Preta Beach, São Sebastião Channel, São Paulo State, Brazil (23o30'S; 49o20'W). The area is a narrow rocky shore that presents a steep slope. The experiments were conducted in a flattened part of this rocky shore, in order to facilitate observations and the sampling procedure.

Four experiments were carried out, using different gastropod species as baits: Stramonita haemastoma (Linnaeus, 1757), Tegula viridula (Gmelin, 1791) Morula nodulosa (C. B. Adams, 1845) and Pisania pusio (Linnaeus, 1758). The shells of these gastropods are frequently used by hermit crabs in this rocky shore (Gandolfi, 1996). The baits were previously collected and frozen one day before each experiment. Five attraction points were chosen, in which all crabs that were inside a circle of $60 \mathrm{~cm}$ diameter were collected. These crabs constituted a previous sample. Then, five traps consisting of nylon net bags containing one crushed gastropod were installed in these points. The traps were put on the bottom, submerged at about $0.5 \mathrm{~m}$ deep, and $2.5 \mathrm{~m}$ apart from each other.
Three samples were taken collecting the crabs in 30min intervals. The crabs collected in the traps were considered "attracted" to the baits. This procedure was carried out for each species of bait gastropod.

All individuals (attracted and collected in the previous sample) were removed from their shells, identified and measured with callipers and optic microscopes with millimetric oculars. Shells were also measured and had their adequacy evaluated based in a visual index modified from Abrams (1978): 1. Hermit crab not visible; 2. Pereopods visible but chelipeds not, 3. Angle up to 90o between chelipeds and the plan of the shell aperture; 4. Obtuse angle between chelipeds and the plan of the shell aperture; 5 . Chelipeds closing the aperture; 6. Shield exposed. The physical condition of the shells was also estimated using a modification of the condition index proposed by McClintock (1985): 1. Shells undamaged and shells covered by epibionts up to $20 \%$ of their surface; 2 . Shells covered by epibionts, incrustations and perforations or broken in less than $4 \mathrm{~mm}$ in the aperture; 3. Shells strongly incrusted and with damages larger than $4 \mathrm{~mm}$; 4 . Shells totally damaged and fragmented.

Data analyses were based on Zar (1984) and were performed at the 0.05 significance level. The loglikelihood $\mathrm{G}$ test was used to compare shell utilization patterns, i.e., shell types, condition, and adequacy, between crabs collected in the previous sample and in the attraction sites (treatment baits). This test was also performed to contrast the frequencies of the crabs of each species collected in these both situations. Analyses of variance (ANOVA) were conducted to compare the mean size of the individuals of the species collected, and to test the null hypothesis that all gastropod baits attract the crabs in the same way. Student's t test was used to compare the mean size and number of individuals of each species between previous samples and attraction sites.

\section{RESULTS}

The previous sample revealed that hermit crab assemblage was composed by three species: Pagurus brevidactylus (Stimpson, 1859) (46 
individuals, 29.41\%), Paguristes tortugae Schmitt, 1933 (67 ind., 49.26\%), and Clibanarius antillensis Stimpson, 1862 (23 ind., 16.91\%). These crabs occupied a total of 12 gastropod shell types. Cerithium atratum, Costoanachis sp., Morula nodulosa, Pisania auritula, and Stramonita haemastoma were the most used ones. Attracted crabs used 14 shell types (Table 1). Shell utilization comparisons between previous samples and attracted crabs were carried out with only the most used shells, and differences were found only for P. tortugae $(\mathrm{G}=23.32, \mathrm{df}=3, \mathrm{p}<0.001)$. Individuals of this species occupied mainly shells of P. pusio in previous sample, while the attracted crabs more frequently used those of $\mathrm{M}$. nodulosa and $\mathrm{S}$. haemastoma. Such a difference was not verified for $P$. criniticornis $(\mathrm{G}=3.24, \mathrm{df}=3$, ns), and not tested for C. antillensis due to insufficient data. The proportion of individuals of each species differed between previous samples and attraction sites $(\mathrm{G}=9.56, \mathrm{df}=2, \mathrm{p}<0.01)$. Paguristes tortugae occurred mainly in the previous sample and $\mathrm{P}$. brevidactylus in attraction sites (Table 1). Clibanarius antillensis did not differ between these two situations. The four gastropods used as baits attracted the crabs in similar ways (ANOVA, $\mathrm{F}=0.813, \mathrm{df}=3, \mathrm{p}=0.505)$. The chemical cues released by the gastropod baits also attracted other organisms as the gastropod Costoanachis sp., the portunid crab Callinectes sp. and some fishes. The three hermit crab species differed in size in the previous sample (ANOVA, $\mathrm{F}=78.995, \mathrm{df}=2$, $\mathrm{p}<0.001$ ) (Table 2), with P. tortugae presenting higher shield length than P. brevidactylus (Tukey: $\mathrm{p}<0.001)$ and C. antillensis $(\mathrm{p}<0.001)$. The two latter species presented similar sizes $(\mathrm{p}=0.952)$. Attracted individuals of $\mathrm{P}$. brevidactylus and $\mathrm{P}$. tortugae presented smaller sizes than those collected in the previous sample (Table 2). This was not verified for $\mathrm{C}$. antillensis.

Shell condition did not differ between attracted crabs and those collected in the previous sample $(\mathrm{G}=2.04, \mathrm{df}=3$, ns) (Fig. 1). However, attracted crabs showed a tendency to use more fragmented shells than recorded in the previous sample. The adequacy of the shells were the same for the two groups of crabs $(\mathrm{G}=5.4, \mathrm{df}=5$, ns) (Fig. 2).

Table 1 - Gastropod shells occupied by the three species of hermit crabs collected in the previous and in the attraction samples in the rocky shore of Preta Beach, São Sebastião, São Paulo State, Brazil.

\begin{tabular}{|c|c|c|c|c|c|c|}
\hline \multirow{2}{*}{ Gastropods } & \multicolumn{3}{|c|}{ Previous sample } & \multicolumn{3}{|c|}{ Attraction sample } \\
\hline & $\begin{array}{l}\text { Clibanarius } \\
\text { antillensis }\end{array}$ & $\begin{array}{c}\text { Pagurus } \\
\text { brevidactylu } \\
\text { s }\end{array}$ & $\begin{array}{c}\text { Paguristes } \\
\text { tortugae }\end{array}$ & $\begin{array}{l}\text { Clibanarius } \\
\text { antillensis }\end{array}$ & $\begin{array}{c}\text { Pagurus } \\
\text { brevidactylu } \\
\text { s }\end{array}$ & $\begin{array}{l}\text { Paguristes } \\
\text { tortugae }\end{array}$ \\
\hline Anachis lyrata (Sowerby, 1832) & 1 & 0 & 0 & 1 & 1 & 3 \\
\hline Cerithium atratum (Born, 1778) & 1 & 11 & 8 & 3 & 12 & 6 \\
\hline $\begin{array}{ll}\text { Columbella } & \text { mercatoria } \\
\text { (Linnaeus, 1758) }\end{array}$ & 1 & 1 & 0 & 2 & 0 & 0 \\
\hline Costoanachis sp. & 4 & 14 & 0 & 1 & 16 & 0 \\
\hline $\begin{array}{l}\text { Cymatium partenopeum (von } \\
\text { Salis, 1793) }\end{array}$ & 0 & 0 & 3 & 0 & 0 & 1 \\
\hline Leucozonia nassa (Gmelin, 1791) & 0 & 0 & 0 & 0 & 1 & 2 \\
\hline $\begin{array}{l}\text { Littoraria flava King \& Broderip, } \\
1832\end{array}$ & 0 & 5 & 0 & 0 & 11 & 0 \\
\hline Nassarius vibex (Say, 1822) & 0 & 0 & 0 & 2 & 1 & 0 \\
\hline Olivella minuta (Link, 1807) & 0 & 2 & 0 & 0 & 3 & 0 \\
\hline Pisania auritula (Link, 1807) & 0 & 0 & 0 & 0 & 0 & 5 \\
\hline Pisania pusio (Linnaeus, 1758) & 0 & 0 & 15 & 0 & 0 & 1 \\
\hline $\begin{array}{ll}\text { Stramonita } & \text { haemastoma } \\
\text { (Linnaeus, 1767) } & \end{array}$ & 0 & 1 & 5 & 1 & 1 & 11 \\
\hline Tegula viridula (Gmelin, 1791) & 0 & 0 & 5 & 0 & 2 & 3 \\
\hline $\begin{array}{l}\text { Morula nodulosa (C.D. Adams, } \\
1845)\end{array}$ & 11 & 5 & 5 & 7 & 14 & 16 \\
\hline Unidentified fragments & 5 & 7 & 5 & 8 & 15 & 2 \\
\hline
\end{tabular}


Table 2 - Size (shield length, mm) comparisons (Student's t test) between C. antillensis, P. brevidactylus and P. tortugae collected in the previous and in the attraction samples. (SD, standard deviation; df, degrees of freedom)

\begin{tabular}{lccccccccc}
\multirow{2}{*}{ Hermit crab } & \multicolumn{2}{c}{ Previous sample } & \multicolumn{3}{c}{ Attraction samples } & $\mathrm{t}$ & $\mathrm{d}$ & $\mathrm{p}$ \\
& $\mathrm{n}$ & $\overline{\mathrm{x}}$ & $\mathrm{SD}$ & $\mathrm{n}$ & $\overline{\mathrm{X}}$ & $\mathrm{SD}$ & & & \\
\hline C. antillensis & 17 & 3.03 & 0.53 & 22 & 2.71 & 0.63 & 1.655 & 37 & 0.106 \\
P. brevidactylus & 29 & 2.87 & 1.41 & 62 & 2.34 & 0.55 & 2.562 & 89 & 0.012 \\
P. tortugae & 62 & 7.24 & 2.09 & 45 & 5.01 & 2.01 & 5.530 & 105 & $<0.001$ \\
\hline
\end{tabular}

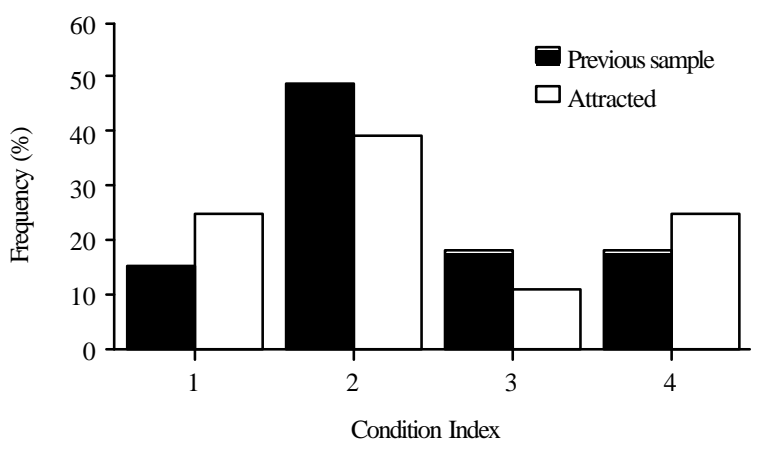

Figure 1 - Shell condition of hermit crabs (pooled the three species) collected in the previous sample and attracted to baits. (Indices: 1 to 4 , see text).

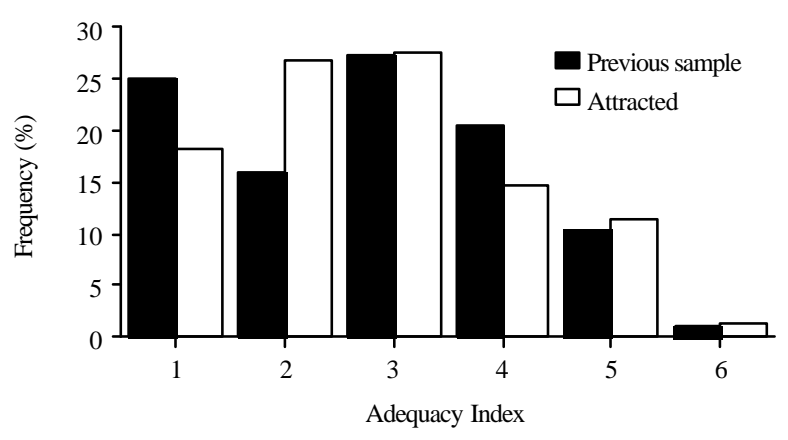

Figure 2 - Shell adequacy to hermit crabs (pooled the three species) collected in the previous sample and attracted to baits. (Indices: 1 to 6 , see text).

\section{DISCUSSION}

The three hermit crab species collected in this rocky shore were common species in intertidal and low subtidal regions in São Paulo State (Fransozo \& Negreiros-Fransozo, 1996) and in São Sebastião Channel (Leite et al., 1998). Shell utilization differed among species and was associated with size differences among them, as also verified by Leite et al. (1998). Pagurus brevidactylus, the population with the smallest individuals, both in the previous samples and attracted, utilised shells of reduced dimensions. These shells were commonly located on macroalgae (A. lyrata, Costoanachis sp.), in the sediment (C. atratum, O. minuta, $N$. vibex), and on rocky shores (M. nodulosa). The small size of these individuals was associated with the environment selected for this study: a macroalgae bed. These sites ae very commonly occupied by recruits of hermit crabs and other species (F. P. P. Leite, pers. obs.), and were considered as nursery for such populations. The two other crab populations $(C$. antillensis and $P$. tortugae) were larger in size and utilized larger shells, which were very common at this location. Rittschof (1980) showed that some species of hermit crabs restricted themselves to preferred gastropod baits, suggesting that chemical attraction 
could be specific. However, the crabs at Preta Beach did not show preferences for a given gastropod species, thus suggesting that the chemical cues are not so specific.

The choice of a macroalgae bed, formed mainly by Sargassum and Acanthophora, as experimental area, certainly influenced the hermit crab's attraction behavior. This assertion was based on the fact that the high complexity generated by macroalgae made hermit crab's movement and orientation to the chemical cues released by the gastropod baits difficult. In addition, attraction of hermit crabs in rocky intertidal zone was less evident than in sloping sandy beaches or mudflats (Hazlett, 1996). This was probably the explanation for the weak evidence of attraction specificity of hermit crabs to gastropod baits at this site.

Gilchrist \& Abele (1984) observed that hermit crabs attracted by chemical signals from injured tissues of gastropods had also carried inadequate and damaged shells, when compared to a nonattracted group of crabs. We expected to find similar differences in the shell quality, but our results were not significant, possibly as a result of the poor quality and the presence of encrustation and physical injuries in all the utilized shells in the study area. Another possibility is that the attraction was not effective due to the presence of the algae as described by Hazlett (1996).

In general, attracted crabs were smaller, had a wide size range and utilised more gastropod shell species than in the previous sample. These trends agreed with similar studies (Gilchrist \& Abele, 1984; Rittschof, 1980; Rittschof et al., 1992), but the larger number of shell species utilised by the attracted group could be a reflection of their smaller size. There were more gastropod species of small size in the study area, and smaller number of species that could grow into a large size (Leite et al., 1998). As a consequence, larger crabs will have few shell species that can fit them. Small crabs can use a wider range of shell species but they need to be constantly acquiring new shells as they grow and moult. This may account for the attraction of smaller individuals they need to constantly change their shells in order to grow. Large adult individuals carrying adequate shells may not respond to the baits, possibly because they do not need a new shell, and so they will be poorly represented at predation sites. This can explain the fact that responsive crabs carry shells of poor quality as also verified by Hazlett \& Herrnkind (1980).

\section{ACKNOWLEDGEMENTS}

We thank the FAPESP for the grants given to J.C.B. Pezzuti and A. Turra (Proc. $N^{0}$ 93/3784-7 and 93/2439-4, respectively), to CNPq for the grant to F.P.P. Leite (Proc. $N^{\circ} 300337 / 82-5$ ) and to the Centro de Biologia Marinha of Universidade de São Paulo (CEBIMar-USP) for laboratory support. We are also grateful to H.E. Hara, B. Ramos, R.H. Nonaka and A. Camargo for field assistance, and to Dr. W. Laurance and R. Gebara for the revision of the manuscript.

\section{RESUMO}

Ermitões utilizam conchas de gastrópodes para abrigo. Conchas novas e mais adequadas podem ser encontradas pelos ermitões pois estes são atraídos por substâncias químicas liberadas pelos tecidos de gastrópodes feridos ou mortos. A adequação, condição e tipo das conchas e a composição de espécies e o tamanho dos ermitões foram comparados entre indivíduos atraídos e os coletados em amostras prévias. Estes últimos ermitões foram coletados em 5 áreas antes de cada experimento. Nestes experimentos, sacos de tela de nylon contendo um gastrópode amassado foram colocadas nas áreas de atração. Foram obtidas 3 amostras por área em intervalos de 30 minutos, coletando-se todos os ermitões dentro de um raio de $30 \mathrm{~cm}$ em volta da isca. Foi testada a atração a iscas de 4 espécies de gastrópodes para observar a possibilidade de especificidade ao sinal químico. Clibanarius antillensis, Pagurus brevidactylus e Paguristes tortugae foram coletados na área de estudo. Pagurus brevidactylus, a menor espécie, mostrou ser mais atraída do que as outras duas espécies. Verificouse que os ermitões atraídos utilizaram maior número de tipos de conchas do que os coletados nas amostras prévias, contudo o padrão de utilização de conchas não diferiu. Os ermitões 
atraídos foram ligeiramente menores (comprimento do escudo cefalotorácico) do que os coletados nas amostras prévias mas não mostraram diferenças significativas na condição e adequação das conchas. Os 4 experimentos utilizando diferentes iscas atraíram os ermitões de forma semelhante não havendo indicação de resposta específica. $\mathrm{O}$ fato dos ermitões atraídos serem menores que os das amostras prévias sugere que a atração aos gastrópodes mortos pode possibilitar a aquisição de conchas novas e maiores e, conseqüentemente, a ocorrência de uma cadeia de trocas de conchas entre os ermitões atraídos

\section{REFERENCES}

Abrams, P. A. (1978), Shell selection and utilization in a terrestrial hermit crab, Coenobita compressus. Oecologia, 34, 239-253.

Bach, C. B.; Hazlett, B.; Rittschof, D. (1976), Effects of interspecific competition on fitness of the hermit crab Clibanarius tricolor. Ecology, 57, 579-586.

Bertness, M. D. (1981a), The influence of shell type on the growth rates and clutch sizes of hermit crabs. Crustaceana, 40, 197-205.

Bertness, M. D. (1981b), Pattern and plasticity in tropical hermit crab growth and reproduction. Am. Nat., 117, 754-773.

Bertness, M. D. (1981c), Predation, physical stress, and the organization of a tropical rocky intertidal hermit crab community. Ecology, 62 : (2), 411-425.

Childress, J. R. (1972), Behavioral ecology and fitness theory in a tropical hermit crab. Ecology, 53 : (5), 960964.

Fotheringham, N. (1976), Effects of shell stress on the growth of hermit crabs. J. Exp. Mar. Biol. Ecol., 23, 299-305.

Fransozo, A; Negreiros-Fransozo, M.L. (1996), Brazilian Coastal Crustacea Decapoda. In - Bicudo, C. E. and Menezes, N. A (eds.). Biodiversity in Brazil, a first approach. Proceedings of the workshop: Methods for the assessment of biodiversity in plants and animals. Campos do Jordão, SP, Brazil. pp. 275-287.

Gandolfi, S. M. (1996), Padrão de utilização de conchas $e$ aspectos da reprodução de Paguristes tortugae $e$ Pagurus brevidactylus (Decapoda, Anomura) em costões rochosos do Canal de São Sebastião, SP. Dissertação de Mestrado, Unicamp, 69 pp.

Gilchrist, S.; Abele, L. G. (1984), Effects of sampling methods on the estimation of population parameters in hermit crabs. J. Crust. Biol., 4, 465-654.
Hazlett, B. A. (1996), Comparative study of hermit crab responses to shell-related chemical cues. J. Chem. Ecol., 22 : (12), 2317-2329.

Hazlett, B. A.; Baron, L. C. (1989), Influence of shells on mating behavior in the hermit crab Calcinus tibicen. Behav. Ecol. Sociobiol., 24, 369-376.

Hazlett, B. A.; Herrnkind, W. (1980), Orientation to shell events by the hermit crab Clibanarius vittatus (Bosc) (Decapoda, Paguridae). Crustaceana, 39 : (3), 311-314. Leite, F. P. P.; Turra, A.; Gandolfi, S. M. (1998), Hermit crabs (Crustacea: Decapoda: Anomura), gastropod shells and environmental structure: their relationship in southeastern Brazil. J. Nat. Hist., 32, 1599-1608. 
Lepore, M.; Gilchrist, S. (1988), Hermit crab attraction to gastropod predation sites. Am. Zool., 28 : (4), 93.

McClintock, T. S. (1985), Effects of shell condition and size upon the shell choice behavior of a hermit crab. J. Exp. Mar. Biol. Ecol., 88, 271-285.

Markham, J. (1968), Notes on the growth patterns and shell utilization of the hermit crab Pagurus bernhardus. Ophelia, 5, 189-205.

McLean, R. B. (1974), Direct shell acquisition by hermit crabs from gastropods. Experientia, 30, 206-208.

Rittschof, D. (1980), Chemical attraction of hermit crabs and other attendants to simulated gastropod predation sites. J. Chem. Ecol., 6 : (1), 103-118.

Rittschof, D.; Tsai, D. W.; Massey, P. G.; Blanco, L.; Keuber Jr., G. L.; Haas Jr., R. J. (1992), Chemical mediation of behavior in hermit crabs: alarm and aggregation cues. J. Chem. Ecol., 18 : (7), 959-984.

Vance, R. R. (1972), The role of shell adequacy in behaviour interactions in hermit crabs. Ecology, 53, 1075-1083.

Wilber Jr., T. P.; Herrnkind, W. F. (1984), Predaceous gastropods regulate new-shell supply to salt marsh hermit crabs. Mar.Biol., 79, 145-150.

Zar, J. H. (1984), Biostatistical Analysis. Prentice-Hall, $2^{\text {nd }}$ ed. 718 pp. 